\title{
Black Women's Sufferings, Resistance to Violence and Insights for Meaningful Life in Toni Morrison's Song of Solomon
}

\author{
Vu Thi Quynh Dung ${ }^{1 *}$, Ph.D, Maria Luisa A. Valdez ${ }^{2}$, Ph.D \\ ${ }^{1}$ Hung Vuong University, Socialist Republic of Vietnam \\ ${ }^{2}$ Batangas State University ARASOF Nasugbu, Republic of the Philippines
}

*Corresponding Author: Vu Thi Quynh Dung, Hung Vuong University, Socialist Republic of Vietnam

\begin{abstract}
Philosophers, psychologists, spiritual leaders, as well as researchers have all pondered on the thought of what makes life worth living. Likewise, different people hold diverse viewpoints about meaningful life.For women and girls, a part of a meaningful life is derived from the liberation of their own lives. In developing countries, women's traditional roles are still family-focused with domestic chore, bearing and rearing children, taking care of her household. In addition to those challenges, they are also oppressed with racial discrimination, sexual violence and domestic violence. As a result, many of them struggle to fight against those so as to pursue a better life. Thus, this qualitative study analyzed the insights on pursuit for meaningful life in Toni Morrison's novel titled Song of Solomon pointing out the events and situations which show implications of the themes pursued in the novel to the study of meaningful life among Vietnamese women and girls. Findings of the analysis revealed that Toni Morrison's Song of Solomon depicted the black women's quest for a meaningful life, which is often complicated by the interconnected web of oppression namely racial discrimination, gender inequality, emotional abandonment as well as women's sufferings. Likewise, the novel showed various manners of women's resistance to different forms of violence. Their final goal for such rebellion lies with the hope to confirm their existence as real persons and gain equal rights with men, to call for a change of perception about their role and reconfirm their status. The themes pursued in the work of Toni Morrison are practically significant for the study of meaningful life among Vietnamese women and girls.
\end{abstract}

Keywords: Black Women's Sufferings, Insights for Meaningful Life, Resistance to Violence, Song of Solomon, Toni Morrison

\section{INTRODUCTION}

The question of man's existence has long since been one of the most challenging questions ever tackled by the greatest of thinkers in history. The multitude of answers that have been made available in the course of time range from the profound to the absurd and man has never been more enthused in searching for the perfect answer. Needless to say, the answer will almost always elude any man who fails to recognize that life itself manifests the reason for being: any form of life exudes the purpose of existence with every tiny facet of its growth in its own pace and in its own moment. Like a seed that grows into a single plant among hundreds that fill a garden, life's meaning can be found in the smallest of detail that can be observed with the changing of seasons[1].

Philosophers, psychologists, spiritual leaders, as well as researchers have all pondered on the thought of what makes life worth living. The responses are diverse based on one's ideological, cultural, social, or religious, and professional backgrounds. Psychiatrist Viktor Frankl once wrote that life is never made unbearable by circumstances, but only by the absence of meaning and purpose [2]. For most individuals, feeling happy and finding life meaningful are both essential and mutually connected goals. But people also pondered if happiness and meaning always harmonize. It seems unconvincing, given that many of the things that people regularly choose to do are unlikely to upsurge their daily happiness.

Contemplating, finding and clarifying their core life intentions and life's purpose can help people to move with greater focus and clarity every day of their lives. In these challenging times, setting clear intentions and developing and refining life's purpose can make it much easier for every individual to 
surpass difficult situations. There are countless ways to find and develop life's purpose and intentions. There are also a number of useful resources to help people on this path of discovery and to inspire them to be all that they can be and to lead them to an ever richer and fuller life [3].

A substantial way to start exploring one's life intention and purpose is to pause for a moment and ask oneself about the most important aspect of human beings' life and what are their deeply-held values and beliefs. Though both can be valuable, there is a difference between life purpose and life intentions. Life purpose consists of the central motivating aims of one's life. Both life intentions and life purpose can be rich and valuable in helping to move through the challenges life brings men, though some prefer focusing on one over the other. If people find this process somewhat challenging, they might do best to focus on one first[3].

Different people hold different viewpoints about meaningful life. Generally, if they possess these five things namely: a faith in God, a meaningful life, a meaningful career, bosom friendship, and the positive contribution to the society, their life will be considered significant. Those five important components boost one another to strengthen the lives of human beings.

For women, a part of a meaningful life is derived from the liberation of their own lives. Throughout the world, governments have committed to achieve the equality between men and women. Women nowadays take part more in the workforce, have more legal rights and more opportunities for education. However, their status in many countries still remains considerably inferior than men in many aspects of life. In developed countries, women are still suffering from unequal wage in the workplace, from sexual harassment, the prevalence of men in political, economic, and other fields.

Likewise, in developing countries, women's traditional roles are still family-focused with domestic chore, bearing and rearing children, taking care of her household. In addition to those obstacles, they are also oppressed with race discrimination, sexual violence and domestic violence. As a result, many of them struggle to fight against those so as to pursue a better life.

Since Vietnamese people are influenced by Confucian philosophy that embraces the patriarchal values, women lead the life, which emphasized the male domination and stressed female subordination. Consequently, discriminations, violence, obstacles and gender disparities were experienced by women. Their work at home and at their workplaces were not seemingly recognized and appreciated. They are expected to perform the noble job of mothers and wives as well as citizens in their country. Their efforts and contributions to family and society were seemingly not recognized as well and they were not accorded with sympathy by the community. Hence, the reason for the search for a meaningful life among Vietnamese women and girls is encouraged.

With reference to the foregoing, literature may be used as a writer's channel is sharing their philosophical thoughts on meaningful existence. It is about human beings and the reflections of their various experiences, ideas, and their daily passions. Through literature, writers share their experiences and readers reminisce their pasts and learn life's lessons through other people's experiences. People find stories designed to portray human life and action through some characters who, by their words, actions and reactions, convey certain messages for the purpose of education, information and entertainment in literature [4]. It is impossible to find a work of literature that excludes the attitudes, morals and values of the society. This idea holds true particularly for prose, which treat life in a more picturesque fashion than any other form of arts.

As regards American literature, Toni Morrison is one among the contemporary black women writers who emerged as an African American star in the twentieth century and who had transformed the American literary landscape in the African American literary tradition. She was an author, editor and critic and was considered as the first African American woman to win the Nobel Prize in Literature in 1993.

The Song of Solomon is a novel written by Toni Morrison in 1977. The novel centers on the life of Macon "Milkman" Dead III, the protagonist of the novel, who was born into a sheltered, privileged life who grows up to be an egotistical young man. He lacks compassion, wallows in self-pity, and isolates himself from the African-American community [5].The said book won the National Books Critics Award, was chosen for Oprah Winfrey's popular book club, and was cited by the Swedish 
Academy in awarding Morrison the 1993 Nobel Prize in literature. In 1998, the Radcliffe Publishing Course named it the 25th best English-language novel of the 20th century [6].

Many writers have been attracted to the theme about women, their lives, their work, and their dreams but few authors wrote about the diverse and complex lives of black women. Toni Morrison took the task of writing about them within the black community as well as holding that community responsible for its own actions.

Black culture and heritage were embraced in Toni Morrison's writings as well as her creative contributions to her black fellows. As a black woman writer, she was able to reach out into the hearts of black women as well as exposed their psychological misery, emotions, feelings, thoughts and desires. In her writings, Toni Morrison engages herself in making the stereotypes of black female characters depicted in most of literary canon, molds a range of vivid new images of black women, and exhibits the conflict in their minds with the stress of racism and sexism and actively established black women's subjectivity [7].

In addition, the black women in Toni Morrison's novels are portrayed as breeding women, maids and domestic workers and treated as commodities to be handled by the white masters. They did not have any human rights whatsoever, but their white masters had all rights over them. Their living condition is full of racism and sexism that resulted in alienation. Exploring human relations was considered the passion of Toni Morrison as her novels tackled racism in the twentieth-century United States as well as the positions of black women within their communities including intra-racial issues.

Toni Morrison's wisdom embodied in her novel may serve as a motivating factor that could help the Vietnamese women re-examine their lives and values. Her writings could provide them views in relation to their attitude towards life in general and towards specific actions in particular. Further, these could also serve as an inspiration and transformation of human acts as Toni Morrison's work delve on philosophy and unique experience. Moreover, this contributes to the social development of the Vietnamese women and girls as members of society, supporting nation building.

The applicability of this research study is highlighted in terms of its implication to academic managers, media practitioners, college instructors of literature, students of literature, the researcher and future researchers. The study may be used as a basis of academic administrators in planning and implementing the curricula that will educate the academic community about the meaningful life regardless of race, gender, nationality and religious backgrounds. Media practitioners may incorporate motivational messages relative to the theme and sub-themes of this paper into various forms of mass media to change the audience's attitudes and behavior and to inspire them to act towards the attainment of a more purpose-driven life. This study may be beneficial for the College Instructors of Literature's methodology specifically in teaching literature using the appropriate literary theories and approaches in literary analysis. This analysis may give students of literature an extensive and profound outlook in life with reference to a person's pursuit of meaningful life through the lives and experiences of the writer and the characters in the literary piece. This paper will be beneficial to the researchers in the sense that this will provide them with opportunities to discuss the concept of meaningful family life in their literature classes and open their students' hearts and minds to the essence of meaningful life as a philosophical and spiritual inquiry. This paper may stimulate the future researchers to conduct more studies on ways that are most effective in integrating a purposedriven life into the people's consciousness to substantiate the present investigation. Furthermore, this study may serve as the writers' modest contribution to the existing limited body of research about the life and works of Toni Morrison.

\section{OBJECTIVES OF THE STUDY}

This study analyzed the insights on pursuit for meaningful life in Toni Morrison's novel titled Song of Solomon pointing out the events and situations which show honest implications of the themes pursued in the novels to the study of meaningful life among Vietnamese women and girls. Likewise, this paper tried to present how the selected works manifest the sufferings of black women in terms of racial oppression, gender inequality, emotional abandonment, and women's sufferings; and the manner how the women in the world portrayed in the novel expresses resistance to the different forms of violence. 


\section{Materials ANd Methods}

\subsection{Research Design}

This study employed the qualitative method of research in analyzing the tenets of black women's pursuit for meaningful life in the representative literary work chosen. Qualitative research, in all of its complex designs and methods of data analysis, according to Suter (2012) [8], is guided by the philosophical assumptions of qualitative inquiry, which aims to understand a complex phenomenon; one considers the multiple realities experienced by the participants themselves-the insider perspectives. These multiple realities experienced by the participants can be manifested in a number of ways, including the literary genre called novel.

Likewise, this study involved content analysis, which is a systematic technique in analyzing message content and message handling. The data analysis in this research centered on pattern seeking and the extraction of meaning from Toni Morrison's novel.Since much qualitative data exists in the form of narrative scripts wherein words or concepts were recorded, meanings were sorted and coded using an organized framework, pondered on the emerging themes, made sense of them, interpretations considered, and conclusions reached. The analysis required the extraction of the best meaning and most trustworthy conclusions.

A categorical analysis according to events in the literature served as coding units to conform with the theories that explain the black women's search for the meaning of life in relation to their sufferings and likewise as aid in the extraction of the theme's implications in teaching meaningful life to Vietnamese women and girls. Thus, events were analyzed categorically according to manifestations of the black woman's sufferings, and the black women's manner of resistance to a particular form of violence.

As interpretative tools in this process, metaphors are useful, serving a guiding role or explaining the elements of a theory. One useful metaphor was introduced by Seidel (1998) [9], which states that qualitative data analysis is best understood as a symphony based on three elegant but simple notesnoticing, collecting, and thinking. Noticing highlights the analysis or the breaking up, separating, or disassembling of research materials into pieces, parts, elements, or units. Collecting focuses on facts broken down into manageable pieces, after which, the researcher sorts and sifts them, and Thinking which emphasizes searching for types, classes, sequences, processes, patterns, or wholes. This process is described as iterative or a repeating cycle, recursive or returning to a previous point [10].

Moreover, this analysis made use of the sociological and philosophical approaches as the bases for analysis. In particular, the sociological and philosophical approaches were supported by Victor Frankl's Theory about the meaningfulness of life. Other approaches in literary criticism such as Formalist Criticism, Biographical Criticism, Historical Criticism, Gender Criticism, and Psychological Criticism are not part of this study.

\subsection{Materials for Criticism}

For the purpose of this study and to give philosophical credibility, the representative literary work analyzed was Toni Morrison's Song of Solomon(1987). It was chosen to parallel the criteria spelled out for the purpose. This work has been taken up in critical analysis far less frequently than the author's most popular books entitled Bluest Eyes, Sula, and Beloved. The themes and practices in Morrison's novel include: ancestors; freedom and "bad" men; good and evil; extreme situations; loss of innocence; responsibility; roots, community and identity; sense of loss;and many others [11].This novel constituted the primary and twining source of the study. The said novel was chosen because of its correlation with the cited theme and subthemes. Other literary pieces of Morrison which have undertones of pursuit for a meaningful life such as Beloved, The Bluest Eyes, Sula, A Mercy, Peeny Butter Fudge, Tar Baby, and many more were not included in the study.

\subsection{Treatment of Materials}

In the conduct of this study, the essential features in the treatment of materials were well thought-out by the researchers. To adopt a more systematic identification of selected works, several norms were adhered. Alkiere (2014) [12] put forth the following criteria: linguistic accessibility, literary accessibility, cultural accessibility and story-telling quality. With reference to linguistic accessibility 
or the criterion which is dependent on how free the novel is from errors in syntax, vocabulary and punctuation, the novel was assured to be free from the aforecited "lexical and grammatical traps." As regards literary accessibility or the criterion which requires novel not to be overtly descriptive or lengthy and should be accessible to the reader, the novel is classified as a full-length novel written in English by an African American writer.

In relation to cultural accessibility or the criterion which involves taking into consideration how bounded the novel is to culture, the literary work clearly expressed insights on the pursuit for meaningful life in the context of the Vietnamese women and girls' lives. Relative to story-telling quality or the criterion which points out that the novel should be a page turner, relevant and appealing to the readers; that the selection must be published from the year 2000 onward to ensure contemporariness and relevancy; and that the novel must focus on insights on pursuit for meaningful life.

Utmost care to ensure the veracity and reliability of the sources from which the necessary materials were selected as part of this study was exercised. Likewise, the material that was included for analysis and criticism was chosen in adherence to the prescribed methodology and criteria. The researchers provided the necessary evaluation and explanation of the language as used in the literature as regards its suitability, relevance and appropriateness to the theme and situation in accordance to the study.

\section{RESULTS AND DISCUSSION}

Toni Morrison's biggest inspiration for writing is to focus on her black people's life, and her Song of Solomon is of no exception. Under her pen, the destiny of those especially black women in the racist, gender unequal, hegemonic culture is scrutinized in different shades, from different perspectives. This part presents the analysis of the novel based on the objectives of the study.

\subsection{The Sufferings of Black Women in Toni Morrison's Song of Solomon}

Sufferings of people are diversified, from sufferings in emotion, cognition and spiritual to other kinds of suffering, such as harmful natural, ecological, political, economic and social conditions. In reality, these interact with each other and have great effects on the attainment of meaningful life [13].Morrison's Song of Solomon manifests the suffering of black women in terms of racial oppressions, gender inequality, emotional abandonment and women's sufferings.

\subsubsection{Racial Oppression}

Oppression is the resulting effect of an able group of people's inconsiderate acts toward another group considered as the weaker class. When met by little or no resistance, the ill treatment worsens into blatant acts of dehumanizing maltreatment by the oppressed group. Racial oppression is no different from the above-mentioned vicious act of marginalizing a group of people, while particularly targeting race of people that is considered by the oppressors as being inferior to their own. Collins (1991) [14] defines this as the classification of people according to race that eventually results to inequality in privilege and power.

In the Song of Solomon, Toni Morrison depicted a white racist society in which black women experience a hard life being women of color. The pervasive oppressive forms are derived from externalized force such as verbal abuse, maltreatment, and even violence from the white perpetrators, as well as from the internalized form of hatred: the pre-conceived notion of being hated for their physical appearance which brings about an internal desire to become white-like women.

Morrison profoundly explained how the idea of racism imposes harm on the lives of the black women as they experience racial prejudice in what is supposed to be service to the public of the Mercy Hospital right from the beginning of the novel."Mercy Hospital," which functions as a charity institution, is supposed to be a place that provides medical treatment for the poor. However, black women have problems in getting access to this charity hospitals' service even in the emergency of giving birth. Being accepted in a hospital, and given medical attention and healthcare is a luxury they could not afford. Thus, a charity hospital offers the only chance they can ever hope to have in such an emergency. It is indeed ironic that the hospital denies expectant mothers' admission due to the color of their skin. The notorious inhumanity of this otherwise presumed benevolent place got its name "No Mercy Hospital" from the colored residents of the city. 
Morrison revealed the truth that in the racist society black women are deprived and stripped of their privileges: Their healthcare which is not being given attention equates to being of no importance to the whites. This finding is in consonance with Burn's(2008) [15] view on the suffering of the black women as victims of racial prejudice, which suggests that deprivation of the most basic of necessities is a clear violation of the black person's human rights.

In a racist society, it is said that there is no law that offers protection to serve the interests of colored people. Racial prejudice can be observed in the novel with reference to the discrimination in the black person's use of public facilities. Long before the declaration of human rights, black people who lived their lives as slaves were not allowed to take passenger trains when they travel. The decision of whether to travel or not, was not a matter of choice for the blacks, but depended solely on their master's decisions. They were considered as commodities or properties, being bought and sold, thus, were "transported" along with the other goods and commodities. They were excluded from using any means of transportation, save for the confines and safety limitations offered by a cramped wagon -the kind of transportation for commodities.

The relegation of blacks to segregated facilities in public transportation comes from racial prejudice and racial discrimination, a vicious cycle that was derived from oppression and resulted to further oppression. This vicious cycle is directed against the blacks. This maltreatment resulted into an even more negative implication on the lives of black people.

The prolonged racial oppression resulted in the black people's acceptance of the oppressors' prejudices. This internalized oppression resulted in the desire to adapt to the conventions of the society. In the white-dominant society, beauty is also subject to judgment that is not without racial prejudice. Through the novel, Morrison wanted to break free from the black person's concept of beauty; a standard instilled in the minds of the first slaves, passed on to the next generation of black people. This concept was born from how the white people saw the black people, ultimately leading to black women looking at themselves through a distorted lens of faulty standards. The black women fell victims to what they thought was the true standard of beauty, and that their physical identity: the color of their skin and eyes, the size of their noses and lips, and the texture of their hair, was unattractive. This caused a negative psychological impact to black women. This finding conforms to Robinson's (2011) [16] view about the disassociations attributed to the internalization of oppression, and how it resulted in the tarnished self-conceptualization in African-American adult women.

Morrison greatly emphasized the different experiences and scenarios that vividly expressed oppression through her written lines in the novel. She showed how the black women were treated as the lowest individuals in the social hierarchy of the society in which they belong. She created a clearer view of the real-life injustices and maltreatments which contribute to the ongoing existence of racism in the black society. Those women were marginalized from their community because of their minority status and their gender.

\subsubsection{Gender Inequality}

Tanzim (2011) [17] explained gender inequality as the resulting marginalization of women as determined by a male-dominated society that provides few if not zero opportunities designed to keep women from elevating their status to a level that is equal to men. Gender inequality exists because of discrimination in the family and societal institutions and social, cultural and religious norms that perpetuate the stereotype, practices and beliefs that are detrimental to women [18]. The novel reflected the suffering of black women in terms of gender inequality in almost all those spheres of life.

In the Song of Solomon, black women were oppressed by the conventions of the society relative to their roles at home, in marriage and in relationships with men. They themselves accepted their inferior role in their lives. Women are certainly biologically weaker than men. However, Morrison does not imply here the physical strength, but the strength from the assumption of the society of the women's role and duty. No matter how hard they try, they cannot get out of the prejudice imposed on them. The society put on their shoulders the burden of childrearing and the bulk of housework. Their world is restricted within the family. These conventions enforce black women to be a submissive group. 
Morison uncovered that rejection by the whites and by men are two entirely different things. In the novel, black women hold an unequal status in marriage and in relationships with men. Ruth's life is a striking example of passivity and dependence on men's decisions. During her childhood years, Ruth's life only revolved around her father because she thought that he is the only person who cares for her. As a grown up, her father arranged her marriage with Macon Dead. It was her father, Dr. Forster and Macon who decided on Ruth's marriage, not her. Ruth's situation, to some extent, is similar to the women who adheres to the Confucian ideology as mentioned by Legge (1966) [19] that requires women to obey their father when they are small, their husband when they are married and their son after their husband's death.

Gender inequality is also reflected in the boundary of the family. The novel gave a vivid picture of the atmosphere in the Dead family where each member feels awkward with fear in the presence of Macon Dead. The harsh patriarchal society makes the lives of the women in the novel miserable. Their lives are restricted to their homes. They are so submissive that without the males' signals they will not decide on nor do anything. Another significant aspect is that Ruth was not respected by her husband. Her days are overwhelmed with Macon's scornfulness from morning until night. Her two daughters were also faced with the strains that their father created over them. The oppression they endure is so hard and so long that they accepted this maltreatment as a part of their lives. Macon rules the family. What women should do, what they will eat, and where they will go for the weekend, is dependent on what Macon orders them. He is also so insensitive of the women's feelings and thoughts. It can be gleaned in the novel that in a male-dominated society, men give themselves the right to maltreat the women in their families. This finding supports Trinh's (2008) [20] view that the father symbolizes the pillar of the house, he holds the absolute authority in decision-making and he deserves to be in this respected position.

Gender inequality spans numerous levels that are observed in the society regardless of culture, with the most common gender bias beginning at home, with the male child deemed to carry on the family surname as opposed to the female child. In addition, males can be relied upon household help that requires physical skill. This physical advantage attributed to males explains the gender bias also observed at the workplace. Sen (2001) [21] outlined the seven levels of gender inequality as manifested in mortality, natality, basic facilities, specialty, profession, ownership and household.

Morrison presented natality inequality through the preference given for a male child rather than a female child. Men believe that, and so do the women. In a family, it is important that the wife give birth to a son to please the husband. It can be gleaned in the novel that after years in a desperate marriage without sex, Ruth meets Pilate and gets her assistance to be impregnated by Macon. Pilate tells Ruth that Macon ought to have a son, or this would be the end of their relationship. This situation showed how women suffered from the unfair treatment in the assumption of the two genders in the society.

Gender inequality is also shown in the treatment between the male child and the female child. In the Dead family, Macon treats his male and female children differently. Throughout the novel, readers can hardly observe Macon's communication with Lena and Corinthian like what a typical father do with his daughters. He is usually annoyed when he arrives home and whenever he sees his daughters. This is quite different with regard to Macon's treatment of his 16-year old son, Milkman.He allowed him to work in his office. He felt proud of him. He told him about the history of his family and he even taught him about their business. Moreover, he intended to leave him all the property that he has earned all his life.

Macon Dead favors Milkman by letting him decide whom to marry and to have offsprings of his own, thus ensuring that his family name and lineage are kept alive. While this father-son bond is understandable, important details stick out like a sore thumb in Macon Dead's philosophy: for example, Macon can show his fondness or preference toward Milkman while being fair if not nice to his wife and daughters, yet he chose to show his ugly side to the women in his family, as if depriving them of his attention can add to Milkman's already bloated sense of self-worth. Another point worthy of criticism is that Macon treats his daughters terribly because he gives importance to the legacy of his family name which cannot be carried or continued by any of his daughters, notwithstanding the fact that his genes, heritage, or lineage can be passed on by any of his daughters to their offsprings. 
Macon's way of thinking is a manifestation of the adverse effects of oppression that made him the uncaring patriarch who cares less for his own blood and more for the name that he inherited as a slave.

Patriarchal conventions with gender bias brought about Lena and Corinthian's sufferings specifically the absence of their father's love for them as well as their right to inherit the fortune. They live in a big house, they travel in a luxury sedan, her father gets a good business, but they do not own anything among those. Macon afforded them privilege to use everything around them, but not in any way an eventual right of ownership. Their father inherited everything from their grandfather by virtue of marriage. Likewise, everything will be bequeathed by Macon to their brother. They do not enjoy the freedom of choice specifically in line with the choice of lives they have to live. When their father passes away, their brother will inherit leadership and essentially, control, influence and power over everyone in the family. This notion supports the Confucian philosophical belief as cited by Legge (1966) [19], which was highly appreciative of the role of the father in the family and a 'must' to have son in each family to assume the duties of his father, to inherit the property and to maintain the succession of the family.

The suffering of black women due to gender inequality is more vividly depicted in the lengthy conversation between Lena and her brother, Milkman. The lengthy conversation disclosed the truth that in a male-dominated society, men are the center of the women's lives. It is the women's duty to serve men unconditionally. It can be gleaned that while the female members of the Dead family were earnestly fulfilling their role as Milkman's babysitters, the acts of kindness that they gave Milkman should have at least earned them his gratitude at the very least. The self-sacrifice required in raising a child should have taught Milkman the value of showing respect, if not love to her sisters. Other children who grew up in the care of non-relatives have been observed to show love and affection toward their nannies, but the care provided for Milkman resulted in a bloated sense of superiority that reeks disregard to the very souls that nurtured him. Milkman could have easily been a key figure in improving the lives of the women in their family, but his status deprives him of the sensitivity to realize their plight. The tribulation of all women in the Dead family results from their biological difference.

In the world of the Song of Solomon, the status of black women at work is also not appreciated. This clearly showed the hardship of black women in their struggle for survival. They experience exclusion from employment due to double jeopardy -- being women and being black. This kind of institutional discrimination makes black women a more occupationally disadvantaged group than black men and the whites. They cannot compete with them, so to earn a living they have no choice but to work at home or in the plantations of the white masters and to live in poor accommodations. These unbalance status with women hurts them mentally and physically. This can be compared with Hasford's (2010) [22] findings that young black Canadian workers were disadvantaged by an unequal playing field comprised of stereotypes and unequal intergenerational legacies, and by racialized interpersonal games played. However, unlike this analysis, his research found out that gender had greater impact at workplace oppression of black males than black females.

Gender inequality is associated with the prejudiced perceptions and treatment based on gender norms which results in gender oppression. It has negative consequences for women. Women are oppressed with the idea that men have the qualities that make them the ideal participants in the emerging public sphere of economy and polity such as being rational, autonomous, active, aggressive, and competitive, whereas women are defined in contrast as emotional, dependent, passive and nurturing - all qualities that deem women's place in the private sphere. Blinded by the power of authority that corrupts a man to the core of his humanity, acts of violence against these people are done, now and then. Situations like these acts are vividly illustrated in the work of Toni Morrison.

\subsubsection{Emotional Abandonment}

Emotional abandonment, according to Lancer (2018) [23], is the state of loss of physical closeness due to death, divorce, and illness or it can happen when the emotional needs are not being met in the relationship even the other person is right beside them. The same state of loss is reflected in the lives of the black women characters in the literary work of Morrison. 
In the Song of Solomon, most of black women suffered from both physical and emotional abandonment. Toni Morrison created Ruth as a typical emotionally abandoned female character in the novel. She was neglected by both her husband and her son. Ruth's situation as described in a few short words does not give justice to the amount of time she suffered in silence. When a human being yearns for affection, any kind-hearted soul cannot afford to look the other way. Ruth is a woman and a wife who is supposed to be the queen of her household, but at such a very young age, the queen resigned to her fate of being lonely and unloved. In other cultures, Ruth could very well be a princess enjoying the attention given to her by princes as suitors, but how Ruth survived all those years of feeling insignificant and unwanted shows a level of fortitude in the most extreme and prolonged case. Even more disheartening is the fact that Ruth is also a mother, and the affection of her son could have filled the emptiness all those years, but all hope for Ruth's chance to be happy was shattered in the person that Milkman turned out to be. Moreover, the door of marriage seems closed to Ruth. There is no emotional connection between her and Macon. She lives quietly in the house, and emotionally and sexually abandoned by her tyrannical husband.

Bennett (2014) [24] pointed out five signs in marriage that are tell-tale signs of emotional abandonment: lack of physical togetherness, long periods of silence, one-sided conversations, feelings of being with a self-centered partner and denial. Ruth experiences all of the five signs of emotional abandonment. Readers will not be surprised in realizing the fact that Ruth comes to the cemetery several times a year. The purpose of her secret journeys at midnight to the place where her father was buried is to talk to somebody who wanted to listen and not to laugh at her. Somebody she could trust and who trust her. She did not care if his father was already dead. It is significant to note that people have the biological need to communicate, to talk, to share their joys and sorrows in life. Ruth is so lonely that she opted to talk to her dead father. As mentioned above, having one-sided conversation was a sign of solitude. Readers might wonder what motive could have then inspire Ruth to travel alone such a long way by bus, then by train at midnight, to her father's grave. The answer is so simple: she is starving for affection. Her simple wish to have somebody to exchange feelings with cannot be fulfilled because nobody cared for her since her father died. She longs for a person to listen to her, but it seems too much of a luxury.

Abandonment in terms of emotions and feelings can lead to difficulties in trusting other individuals particularly those inside a relationship. Fear of intimacy is expressed usually by the subconscious, which can come up with results like pulling away, putting up walls, or pushing the other person away. Often, this abandoning behavior occurs after a period of closeness or sex. One person may physically withdraw or create distance by not talking or even by talking too much. Either way, it may leave the other person feeling alone and abandoned [25].

This behavior, as an offshoot of abandonment due to mistrust, will also contribute to unhealthy communication patterns, in which one or both partners do not share openly, listen with respect, and respond with interest to the other. This can be very harmful to a relationship over time. When people are ignored or their partners do not understand or care about what they are saying, they may eventually shut down. Walls begin to build and they find themselves living separate lives emotionally [25].

In the novel, men take control in relationships. When they no longer feel those interesting, they try to give up their partners. Then women turned out to be the victims of abandonment. The affair between Milkman and Hagar is a striking example. Milkman's decision to abandon Hagar reflected the kind of person he sees himself to be, and likewise manifested how unmanly he really was, as seen in his insensitivity to his wife's feelings. He regards himself so highly that he deemed it acceptable to end his relationship by writing a farewell note to her.

Hagar's earnest fulfillment of her role in the relationship led to high hopes of unending love. Although these high hopes ended her up broken hearted, it can be learned that Milkman's farewell letter could have been an additional insult to injury. Yet, this could also be a blessing in disguise as Milkman was not an ideal man worth sharing a woman's life with.

The other woman who experienced abandonment in the novel was Pilate. The analysis uncovered Pilate as a woman who is totally deserted by the society. Although she has very strong characteristic, Pilate cannot avoid the feeling of solitude in such circumstance. Human relationship is important for human's existence. Life is meaningless to one when people around turn their back on him. The cause 
of their indifferent behavior for isolating her is unreasonable -- because she has no navel. It was not her fault, but she has to suffer the estrangement of the community. The denial of having a partner, friends, relatives, religion really made Pilate's life miserable. The findings in line with emotional abandonment conform to the Confucian philosophical belief as cited by Legge (1966) [19] on the status of women in the family and in the society in which men take control in all spheres including the relationships.

Emotional abandonment becomes a very significant aspect of the sufferings of black women in Morrison's novel, Song of Solomon. Morrison explained the different forms of abandonment such as the lack of physical togetherness, long periods of silence, one-sided conversations, feelings of being with a self-centered partner as experienced by the female characters in her novel. These forms of abandonment paved the way for these characters' oppressed condition in their society.

\subsubsection{Women's Sufferings}

Tanritanir (2012) [26] claimed that colored women suffer a lot of difficulties to live in a patriarchal community not only because they are female but likewise because they have black skin. They are separated from the society. They have to endure all the violence and discriminating behaviors of both white men and women. In addition to these, colored women also suffer at the hands of black men.

Violence is recognized as a human rights violation. The United Nations Declaration on the Elimination of Violence against Women defines violence against women as any act of gender-based violence that results in, or is likely to result in physical, sexual or psychological harm or suffering to women, including threats of such acts, coercion or arbitrary deprivation of liberty, whether occurring in public or in private life [27]. In other words, gender-based violence includes three types: physical abuse, emotional abuse and sexual abuse. Those are forms of abuse rooted in gender inequality.

In the novel, physical domestic violence against women is very much evident in the Dead family. Having an unhappy marriage, Ruth experiences such aggressive acts from her husband more than once. The literary analysis revealed that Macon treats his wife cruelly. Whenever he feels annoyed with her, he hits her, mostly on her face, in front of their children, and even during mealtime. Obviously, Ruth's marriage was a living hell, but she seems reconciled to it. She is brutally beaten by her husband, with whom she has had three children with. The husband, who married her as part of a plan to climb up the social ladder, and onto the higher steps of the society, was the man whom she devoted her whole life with.

Ruth's misery is not restricted only to humiliation from her husband. The son, with whom she had to bear a lot of pain just so that he could be born, is also very indifferent to her. This son confesses that he has never loved his mother but has always known that she has loved him. Moreover, being selfish, together with the hatred of bearing the name "Milkman," her son sometimes becomes suspicious that his mother did something bad with his grandfather. How miserable Ruth is when both the two closest people doubted her. Ruth is no stranger to both her husband's and son's negative thoughts about her. She accepted her destiny with resignation.

Laughter is very important for people, especially for women. It reduces anxiety and stress. However, Ruth, the daughter of the doctor - the most respected Negro in town, whose husband is a successful businessman and who is never worried about earning a living, rarely laughs in her life. She is oppressed so hard that since the birth of her son, she hardly hears his mother's laughter. If she does, it is just a little faint sound. Indeed, life offered Ruth very little joy that she almost never had a chance to enjoy it.

In the novel, Morrison created various female characters who face numerous forms of oppressions simultaneously. Beside physical violence, they also have to confront sexual abuse. Pilate experienced a traumatized life during her childhood years. The analysis showed that being motherless by the time she was born, Pilate has to manage to earn her own living. In such a tough journey, the inexperienced girl becomes the victim of the sexual abuse by the preacher. She feels helpless, but she is too innocent to protect herself. Nobody has ever told her about that kind of offense before. Consequently, she is even expelled by the preacher's wife for threatening her family life. In this case, Pilate is obviously the one who suffers in silence, but she now becomes the scapegoat. The misfortune does not seem to leave Pilate. She then has a love affair with several other men. Nevertheless, they all come and go, after being satisfied with their sexual desires and realizing her unnatural mark of having no navel. 
Pilate's life represents all the sufferings that a black woman has to deal with in the white society, from being physically and emotionally abandoned by the family, being sexually abused and alienated by the people in the community, marginalized by the white in finding job, so on and so forth. Life's hardships seem to crush this woman. This conforms to Rochmawati's (2007) [28] conclusion about the life of Afghanistan women who have limited privileges in terms of human rights due to the three decades of armed conflicts and its significant impact on their status and situation.

To summarize the main points, Toni Morrison portrayed the different sides of sufferings among black women in the novel. The sufferings include racial oppression, gender inequality, emotional abandonment, and women's suffering. They are discriminated by the white society because of their origin. They are seen as objects that do not have feelings. Those black women suffer from several kinds of humiliations in life. They cannot have a normal life because they are black and they are women in a male-dominated society. Through the medium of literature, Morrison enables readers to be acquainted with a variety of female characters as well as vicarious experiences they involve in life. By doing so, she unintentionally reveals her vivid sympathy with the female community, and that makes her a great writer.

\subsection{Manners of How the Women in the World Depicted in the Novel Expresses Resistance to the Different Forms of Violence}

Resistance is a result of oppression. It is an individual's conscious or unconscious defiance to unjust power or oppression. Oppressed people respond in different manners to different forms and extent of oppression. Martin Luther King, Jr. (1958) [29] stated three characteristic ways oppressed people deal with their oppression. First is acquiescence wherein the oppressed passively accepts an unjust system, adjusts, cooperates, and becomes conditioned to it, thus, nothing is accomplished for the oppressed and oppressors believe that their actions are morally right. Second is violent resistance wherein the oppressed resorts to physical violence and corrodes hatred, creating bitterness in the survivors and brutality in the destroyers, bringing temporary victories but never permanent peace. Third is nonviolent resistance wherein one must be aware of the serious problem and think of ways to fight it, however without violence, seeking to reconcile the truths of two-opposites - acquiescence and violence while avoiding the extremes and immoralities of both.

In the novel, the black women dealt with their oppression in several diverse ways. Women in the Dead family, being the inferior family members, exhibited acquiescence. For many years, they endured Macon's cruelty.

The literary piece revealed Macon as an oppressor who takes full control of his home whether he is at home or not. The women are too accustomed to his unjust and arrogant behavior and they just accepted the situation and manifested no sign of resistance. Knowing that their presence annoys Macon, they passively accepted his ill treatment for their immediate comfort and safety. Acquiescence is a passive surrender to oppression and acceptance of unfair domination.

However, not all of the oppressed women in the novel conform to the sufferings they have. Instead, they exercise another form of resistance, verbal resistance, to cope with the oppression imposed on them.

Years of silence in an oppressive situation are often taken as a sign of acceptance. Verbal outbursts result from a buildup of emotions for every form of oppression that a person endures. Through this outburst, the victim gives the oppressor an idea of the extent of damage done and the feelings of the oppressed about the situation. This might not change his view immediately, but to some extent, he has to rethink of his attitudes and actions toward them. Lena's first-time verbal outburst is clearly an indication of her awareness of the women's suffering in their household. Her demand for freedom from male dominance is an expression of the black woman's identity that desires recognition and respect. The show of her emotion added to the intensity of her desire to manifest resistance against male tyranny. In fact, it is her way of rejecting the patriarchal domination under which she has been living. Unlike the usual mild reaction towards Macon, Ruth's attitude towards Hagar's intention of killing Milkman is ferocious. She kicked the door, moved very fast and came to Pilate's house with the same determined tread as when she goes to the cemetery.

The complexity of the character's motivations may seem to be intertwined in a web of conflict. But a careful analysis revealed that this matrix of interconnection stemmed from a common source: the 
subdued nature of women resulting from male domination. Hagar's actions represent a black woman's desire to fight back against unfair treatment, abuse of female weakness and exploitation. Ruth's protective nature as being part of her motherly instinct is self-explanatory, although Hagar's connection to Macon, who is Ruth's long-time tormentor, adds to the conflict.

In the novel, it is noteworthy to mention that the black women not only resist verbally but physically as well. Physical resistance can be divided into two types: non-violence and violence. Non-violence physical resistance referred to actions or activities employed to get out of the oppressive circumstances while violent physical resistance relates to armed resistance to fight against the oppressors.

In their quest for freedom and equality, Pilate takes the way of nonviolent resistance. The life has pressed her hard since she was born, but she has never rebelled or reacted negatively. Under any circumstances, she tries her best to overcome them. The way she resists to the sufferings did no harm to anybody and to herself. Pilate's experience in life taught her the necessary values that aided her in her pursuit towards a better life. Her choice to disregard whatever it is that others may think of her is a manifestation of her goal-oriented focus. Her concern toward personal relationships as opposed to being affected by stranger's assumptions show her confidence in her wisdom gained from previous experiences. This explains her openness to being helpful to others as part of her goal in finding meaning in life.

However, Pilate's resistant manner totally changes when her beloved girl was threatened. She was so furious when Reba's boyfriend asks her for money and hits her. It is the maternal love that inspires Pilate to protect her only daughter in such a furious way. What the man does to Reba makes her mad, and in that moment, she has no other choice but to resort to a violent resistance. Her ferocious action aimed at threatening the young man so that the latter will not hurt her only daughter.

Hagar has been in that same situation when Milkman abandoned her. She is so desperate that she finds the weapons and seeks for him to revenge. This is a kind of a violent resistance. Hagar's character was lucky to have been showered with love and affection by the women who raised her. Her love for Milkman exemplified this, as can be explained by her yearning for requited love. Her resentment and anger toward Milkman, and her wanting to take his life is a manifestation of a black woman's frustration in spite of earnest efforts. This erstwhile honest intention to love and be loved prevented her from taking another person's life at the very last minute.

To sum up, resistance is the byproduct of oppression. With the first inkling of exploitation and oppression come the seeds of struggle to throw off those who would exploit and oppress [30]. Black women in the novel are all mistreated by the people around them and they always resisted and rebelled for a better life. They who dealt oppression through acquiescence, physical violence; and non-violence resistance. The types and degrees of resistance vary from one another. Resistance brings black women out of objectification and gives them strength and existence as able subjects of a meaningful life.

\subsection{The Implications of the Themes in the Novel to the Study of Meaningful Life among Vietnamese Women and Girls}

By trying to take an overall view of the analyzed themes in the novel about black women's oppressions, as well as the manners of their resistance, readers may understand in greater depth the different facets in the lives of black women.

With regard to the theme of the sufferings of black women, the novel revealed a clearer view of real-life injustices and maltreatment which contribute to the ongoing existence of oppression in the black society. Those women were marginalized in their community because of their minority status and gender. Moreover, the author also indirectly condemned the racists, and patriarchal ideology which marginalized black women and which made them underprivileged both in their families and in their society.

It is significant to note that the literary piece may have a big impact among Vietnamese readers particularly to the women and girls. The novel may teach them moral issues that men and women of all races should have equal rights, live in their own ways and have freedom to pursue their own interests and aspirations. Oppressing others is a violation of human rights. Everyone has a chance to live and be treated equally. 
The novel may also enlighten them as regards the barriers to women's education. Education does not just rely on resources. It is also about beliefs and attitudes- the belief that women and girls are worthy of an education; that their bodies are their own; their minds do matter; their voices should be heard; and that women should have roles outside of their homes. The ability to read, write, and analyze, the confidence to stand up for their rights, and demand justice and equality; the connections and qualifications- all of those starts with education. All women and girls worldwide understand this need. They yearn for it and they will do whatever it takes to earn that education which would eventually lead to a meaningful life.

Education may pave the way in ending all forms of oppression against women and girls. It is not only a fundamental human right but it is likewise, crucial to accelerating sustainable development in the country. It has been proven time and again, that empowering women and girls through education has a multiplier effect, and helps drive up economic growth and development worldwide. Affording women equal rights to economic resources such as land and property are vital targets to realizing one of the goals of the 2030 Agenda for Sustainable Development, specifically Goal No. 5 which centers on the achievement of gender equality and empowerment of all women and girls [31].

Relative to the theme of manners of resistance, the novel showed the readers the various ways of resistance adhered to by the women to achieve their purposes in life. The manners of resistance depend on the situations and the personality of each character in the novel. Some live acquiescently with the sufferings; some carry out violence resistance while others prefer a peaceful one. It is a fact that keeping silence or complaining makes no change at all. Forceful manner may gain the target more quickly, but it seems to reduce the support of the victims. The non-violent one may take more time, but it is much more effective because it leaves no adverse consequences.

Through the literary piece, it is also worth noting that the Vietnamese women and girls may realize that in the modern times, peaceful negotiation is more significant than opposition although occasionally violent resistance is necessary. They should learn to apply appropriate manner of resistance to different situations They need to deal with obstacles positively. Under any circumstance, they should learn that where there is a will, there is a way.

In the boundary of the family, nonviolence resistance is especially recommended to Vietnamese women. To deal with any family conflict, they have to bear in mind that non-violence does not just mean not doing violence; it is also a way of taking positive action to resist oppression or bring about change. Mahatma Gandhi once said that "Nonviolence is an active force of the highest order. It is soul force or the power of Godhead within us." He added that "The essence of non-violent technique is that it seeks to liquidate antagonisms but not the antagonists." Martin Luther King, Jr., on the other hand, underscored the need for "a courageous confrontation to evils by the power of love". Nonviolence resistance has greater effects than any other form for both the resister and the opponent. It enables them to avoid external physical violence and internal violence of spirit. Nonviolence resistance seeks to win friendship and understanding, which are essential in any relationship. Therefore, nonviolence resistance is the best choice when oppression or violence is unavoidable. Adhering to this, the Vietnamese women and girls may attain a meaningful or purposely-driven life.

\section{CONCLUSIONS AND RECOMMENDATIONS}

Toni Morrison's Song of Solomon depicted the black women's quest for a meaningful life, which is often complicated by the interconnected web of oppression namely racial discrimination, gender inequality, emotional abandonment as well as women's sufferings. Likewise, the novel showed various manners of women's resistance to different forms of violence. Their final goal for such rebellion lies with the hope to confirm their existence as real persons, to gain equal rights with men, and to call for a change of perception about their role and reconfirm their status. The themes pursued in the work of Toni Morrison are practically significant for the study of meaningful life among Vietnamese women and girls. Being educated with the nature of a purpose-driven life will motivate Vietnamese women and girls to strive for it. From the foregoing findings and conclusions, the researchers offer the following recommendations: College instructors of literature may exploit this study as the reference in their course in terms of literary theories, literary approaches and philosophical aspect of meaningful life to develop their students' appreciation and sense of value of the analyzed issue. The students apply the result of this analysis as a basis in reconsidering their family life; clarifying what is significant to bring about a meaningful life, and then committing 
themselves for the actions striking forward a better life for all members of their families. Finally, that future researchers conduct other literary works in line with the recent research for academic enrichment to have a cross dissections of interpretations of life and to support the present study.

\section{ACKNOWLEDGMENTS}

Dr. Vu Thi Quynh Dung would like to thank the officials, faculty members and students of the Foreign Language Department of the Hung Vuong University, Vietnam for their generous support and spiritual assistance; Prof. Dr. Maria Luisa A. Valdez, her co-researcher and adviser, for her kindest assistance and for having given the researcher many opportunities to challenge herself during the writing process; and her husband and daughters for without their loving support and encouragement, this paper would not have been made possible.

Prof. Dr. Maria Luisa A. Valdez wishes to express her grateful appreciation toDr. Vu Thi Quynh Dung, for the invaluable effort she has put in on this study as her co-researcher. To Prof. Dr. Tirso A. Ronquillo, the Batangas State University President and the other University officials most especially to Prof. Dr. Erma B. Quinay, the Vice President for Academic Affairs, Engr. Albertson D. Amante, the Vice President for Research, Development and Extension Services and Prof. Enrico M. Dalangin, the Bat State U ARASOF Nasugbu Executive Director, for the motivation that helps hasten the completion of this study. To Mr. Thaak or Pathak, for his wisdom that drew up essential and relevant dimensions in this research. To the pool of writers whose works were included in this study for posterity, for their emboldened wisdom in every page of this research. To the Almighty God and to all of you, the researcher owes her deep gratitude.

\section{REFERENCES}

[1] Society of Kabalarians of Canada Website (2014). What Is My Purpose In Life; Retrieved from: https://www.kabalarians.com/cfm/articles/what-is-my-purpose-in-life.cfm; date retrieved: 02/24/2019.

[2] Frankl, Vicktor E. (1959). Man's Search for Meaning. Buccaneer Books, Inc. New York, USA.

[3] Weboflove.org Website (2019). Life Purpose and Life Intentions: Ideas on How to Find What the Purpose of Life is For You; Retrieved from: https://www.weboflove.org/lifepurposeintentions; date retrieved: 02/24/2019.

[4] Duhan, Roshni (2015). The Relationship between Literature and Society. April 2015, Vol. 15 Issue 4, p192-202.

[5] Morrison, Toni (1987). Song of Solomon. New York: Plume.

[6] Swedish Academy (1993) "The Nobel Prize in Literature 1993" (Press Release). Swedish Academy. 199310-07; date retrieved 01/06/2009.

[7] Li-juan, J. (2012). “Black Women Images by Toni Morrison”, In US-China Foreign Language. April 2012, Vol. 10, No. 4, Dalian Polytechnic University, Dalian, China.

[8] Suter, N. William (2012). Introduction to Educational Research: A Critical Thinking Approach, 2e SAGE, California.

[9] Seidel, J. V. (1998). Qualitative Data Analysis. Retrieved from: http://www.qualiresearch.com; date retrieved 01/06/2009.

[10] Fikfak, Jurij, Frane Adam, Detlef Garz (2004) Qualitative Research: Different Perspectives, Emerging Trends. ZRC Publishing, Institute of Slovenian Ethnology.

[11] Shodhganga.inflibnet.ac.in Website (2015). Narratology in Relation to Theme. Retrieved from: http://shodhganga.inflibnet.ac.in/bitstream/10603/10541/6/06_chapter2.pdf; date retrieved: 10/23/2015.

[12] Alkire, Scott (2014). Teaching Novels in EFL/ESL Classes; Retrieved from: http://www.lingua.org.uk /novteach.alkire.html; date retrieved: 15/10/2014.

[13] Diehl, Ulrich (2009). Human Suffering as a Challenge for the Meaning of Life, Volume 4, No 2, Fall 2009 ISSN 1932-1066.

[14] Collins, Patricia H. (1991). Black Feminist Thought: Knowledge, Consciousness, and the Politics of Empowerment. Boston: Unwind Hyman.

[15] Burn, C. E. M. (2008). Toni Morrison's Beloved Analyzed in the Context of the African American Experience of Slavery, and Slave Narratives, Literary Study Online Website; date retrieved: 20/10/2014.

[16] Robinson, F. C. (2011). Understanding Internalized Oppression in African American Young Adult Women: An Examination of the Impact of Internalized Oppression on Self-Conceptualization. Published Dissertation. The University of West Georgia. 
[17] Tanzim, (2011). Dimensions of Gender Inequality \& It's Impact on Society. Published Dissertation. University of Dhaka.

[18] United Nations Human Rights (2014). Women's Rights are Human Rights. United Nations Publications. Retrieved from: https://www.ohchr.org/Documents/Events/WHRD/WomenRightsAreHR.pdf; date retrieved: 23/10/2014).

[19] Legge, J. (1966). The Four Books: Confucian Analects, the Great Learning, the Doctrine of the Mean, the Works of Mencius. Taipei: Wenxin shudian.

[20] Trinh, Ton Nu Luong (2008). Vietnamese Traditional Family Values. http://www.vietspring.org/values/ traditionalval.html; date retrieved: 16/10/2014.

[21] Sen, A. (2001). Many Faces of Gender Inequality, India's National Magazine, Volume 18 - Issue 22, Oct. 27 - Nov. 09, 2001.

[22] Hasford, J. (2010). "Young, Working and Black: A Study of Empowerment, Oppression, Race and Gender in Community Settings". Published Dissertation. Wilfrid Laurier University.

[23] Lancer, Darlene (2018). What is Emotional Abandonment? Retrieved from: https://psychcentral.com/lib/ what-is-emotional-abandonment/; date retrieved: 02/24/2019.

[24] Bennett, Travis (2014). 5 Emotional Abandonment Signs in Marriage; Retrieved from: http://en.wikipedia. org/wiki/Abandonment_(emotional) ; date retrieved: 6/7/ 2014.

[25] Lancer, D. (2012). What is Emotional Abandonment. Retrieved from: www.whatiscodependency.com/ what-is-emotional-abandonment/; date retrieved: 20/10/2014.

[26] Tanritanir, B. (2012). The Suffers of Black Women in Alice Walker's Novels the Color Purple and Meridian and Toni Morrison's Novels Beloved and The Bluest Eyes. The Journal of International Social Research, Volume: 5 Issue: 23.

[27] United Nations (1993). Declaration on the Elimination of Violence against Women. Retrieved from: http://www.un.org/documents/ga/res/48/a48r104.htm;date retrieved: 15/10/2014.

[28] Rochmawati, (2007). Oppressions Faced by Black Women Characters in Toni Morrison's The Bluest Eye. Published Dissertation. The State Islamic University of Malan.

[29] Luther King, Jr., Martin (1958). Three Ways of Meeting Oppression. Retrieved from: https://www. everettsd.org/cms/lib07/WA01920133/Centricity/Domain/462/11AP\%20MLK\%20on\%20Meeting\%20Op pression.pdf ; date retrieved: 02/24/2019.

[30] Hales, Larry (2009). Oppression Breeds Resistance. Retrieved from: https://www.workers.org/2009/us/ oppression_0319/; date retrieved: 18/7/2014.

[31] Ph.undp.org Website (2019) Sustainable Development Goals: Goal 5: Gender Equality; Retrieved from: http://www.ph.undp.org/content/philippines/en/home/sustainable-development-goals/goal-5-genderequality.html; date retrieved 02/27/2019.

\section{AUTHORS' BIOGRAPHY}

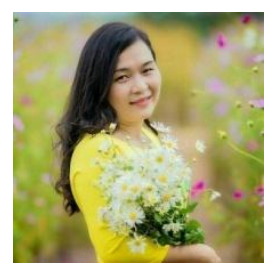

Dr. Vu Thi Quynh Dung is the Dean of Faculty of Foreign Languages, Hung Vuong University, PhuTho Province, Vietnam. She has been in the teaching profession for 25 years. Her primary areas of teaching are English and American Literature, Phonetics and Phonology and writing skill. She has been the mentor for a lot of researches and graduation papers of students. She has presented ten (10) papers on several university journals. Likewise, she is an editorial board member and a peer reviewer of two university journals. Her research interest includes education, humanities and social sciences specifically on contemporary social issues such as education, gender equality manifested in the selected contemporary literary works in English.

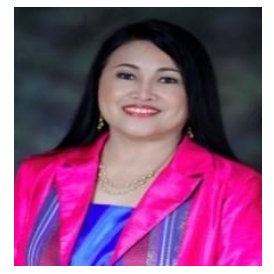

Dr. Maria Luisa A. Valdez is a Professor and the Associate Dean of the College of Arts and Sciences in the Batangas State University ARASOF Nasugbu Campus, Nasugbu, Batangas, Philippines. She has been in the teaching profession for more than 30 years. She is also a senior accreditor of the Accrediting Agency of Chartered Colleges and Universities in the Philippines conducting program assessment among various state universities and colleges. She has published fourteen (14) researches in reputable international refereed journals and presented papers on various local, national and international research fora. Likewise, she is an editorial board member and a peer reviewer of eleven (11) international refereed journals. Her papers won the Best Research Paper Awards in local and international research conferences. Her research interests center on education, humanities and 
social sciences specifically on contemporary social issues like peace education, gender equality, and environmental issues manifested in the selected contemporary literary works in English. She is a visiting professor and the dissertation adviser of seven (7) Doctor of Philosophy students of the Thai Nguyen University International Training and Development Center, Socialist Republic of Vietnam.

Citation: Vu Thi Quynh Dung, et.al. “Black Women's Sufferings, Resistance to Violence and Insights for Meaningful Life in Toni Morrison's Song of Solomon”. International Journal on Studies in English Language and Literature (IJSELL), vol 7, no. 3, 2019, pp. 1-16. doi: http://dx.doi.org/10.20431/2347-3134.0704001.

Copyright: (C) 2019 Authors. This is an open-access article distributed under the terms of the Creative Commons Attribution License, which permits unrestricted use, distribution, and reproduction in any medium, provided the original author and source are credited. 